\title{
NEW RECORDS OF TWO LUTJANUS SPECIES (TELEOSTEI: PERCIFORMES: LUTJANIDAE) WITH RE-DESCRIPTION OF SIX LUTJANIDS FROM SAINT MARTIN'S ISLAND OF THE BAY OF BENGAL, BANGLADESH
}

\author{
Shilpi Saha, Sanjay Chakraborty, Subrina Sehrin, Abdullah-Al-Masud, \\ Kazi Ahsan Habib ${ }^{1}$ and Mohammad Abdul Baki*
}

Department of Zoology, Jagannath University, Dhaka-1100, Bangladesh

\begin{abstract}
Investigations on Snapper fish of the genus Lutjanus were conducted from October 2015 to April 2016 in the coral ecosystem of St. Martin's Island, Bangladesh. Twenty one individuals of 8 species of Lutjanus were collected from local fishermen. Both morphological characters and DNA barcoding approach by mitochondrial cytochrome oxidase I subunit (COI) were used to confirm the identification of all species. Present study recorded the first national occurrence of two reef associated Lutjanus species ( $L$. xanthopinnis and $L$. indicus). In addition six species (L. rivulatus, $L$. lutjanus, $L$. vitta, L. lemniscatus, L. fulviflamma and $L$. johnii) were re-described. Distinct morphological differentiation were found between more closely related species $L$. xanthopinnis, L. vitta and $L$. lutjanus. Three different appearances of $L$. johnii, two different appearances of $L$. rivulatus and L. lemniscatus were confirmed as same species. Phylogenetic analysis showed monophylotic clade for conspecific individuals and paraphyletic clade for congeneric individuals. Average genetic divergence for intraspecific level was $1.5 \%$ and $12.5 \%$ for interspecific level. Current study increased the number of Lutjanus species in Bangladesh from 15 to 17 and extended the distribution range of those new recorded species in northeastern part of the Bay of Bengal.
\end{abstract}

Key words: Coral ecosystem, morphomeristics, cytochrome oxidase I subunit (COI), L. xanthopinnis, L. indicus

\section{INTRODUCTION}

Lutjanus species were distributed along the Indo-West Pacific coast and recorded 43 species (Bloch 1790). In the past, total 15 Lutjanus species were recorded based on morphological characters only from the Bay of Bengal, Bangladesh. However, due to morphological similarities between species, taxonomy of Lutjanus is still highly complex. There are three species L. stellatus, L. buccanella and L. campechanus (Sarker et al. 2015), 8 species L. argentimaculatus, $L$. bohar, L. gibbus, $L$. lemniscatus, $L$. lunulatus, $L$. lutjanus, $L$. rivulatus and L. sebae (Rahman et al. 2009) and 4 species L. sanguineus, L. fulviflamma, L. malabaricus and L. johnii by (Tomascik 1997) in the bay of Bengal, Bangladesh were recorded.

\footnotetext{
*Author for correspondence: <mabaki@gmail.com>. 1Department of Fisheries, Sher-e-Bangla
} Agricultural University, Dhaka-1207, Bangladesh

(c) 2018 Zoological Society of Bangladesh DOI: http://dx.doi.org/10.3329/bjz.v46i2.39056 
The variation of mitochondrial cytochrome oxidase I gene (COI) is moderately high between species and very little between the individuals of a given species (Gross 2012). As COI gene has proven to be highly effective at discovering newrecorded and new species (Gao et al. 2011, Gin et al. 2013). DNA barcoding can accurately link the larval stages of a species, which is usually difficult but using both tools the morphological and DNA barcoding approach apply on single species identification will lead more confirmation of the species. DNA barcoding can be a very effective tool in assessment of cryptic species. Iwatsuki et al. (2015) mentioned that L. lutjanus, L. xanthopinnis and L. vitta are cryptic species. Therefore they are morphologically similar but genetically distinct. Furthermore, L. johnii, L. rivulatus and L. lemniscatus show different marking patterns in different size also (Anderson et al. 2001). Therefore, misidentification could be done in systematics of Lutjanus spp using only one identification tool. The current paper will describe eight species of Lutjanus based on both morphomeristics \& DNA barcoding with two new records and differentiating them correctly from their related congeners and establishing link between conspecifics. This study will be helpful to fishery management, biodiversity conservation, and sustainable exploitation of these species.

\section{MATERIAL AND METHODS}

Specimen collection and deposition: Fish specimens were collected from local fishermen of St. Martin's Island (Fig. 1) $\left(20^{\circ} 34^{\prime} \mathrm{N}-20^{\circ} 38.8^{\prime} \mathrm{N}\right.$ and $92^{\circ} 18^{\prime} \mathrm{E}-$ $\left.92^{\circ} 20.8^{\prime} \mathrm{E}\right)$ during October, 2015 to April, 2016 visiting five times. Local fishermen catch these fishes using gear named small berjal, hooks and lines. Fresh fish deliveries from other areas to St. Martin's Island never occurred so, fish found on fish shop and fish landing zone of this island were considered to originate from waters surrounding the Island. All specimens were collected in full observance of local government regulation, and in obedience to appropriate animal care standards. Most specimens were photographed after collection. Than specimens were transported with ice box to fisheries lab, department of Zoology, Jagannath University, Dhaka and kept in $-20^{\circ} \mathrm{C}$ within deepfreeze till further study. After study, all specimens were deposited in the museum of Zoology department, Jagannath University as voucher specimen.

Morphometric, meristic and molecular analysis: All measurements were made to the nearest $0.01 \mathrm{~cm}$. Methods of morphometrics and meristics are mostly same with those described in Allen and Talbot (1985). Most specimens were photographed when fresh. Counts included: dorsal fin spines and rays (D), anal fin spines and rays (A), pectoral fin rays (P), pelvic fin spines and rays (V), caudal fin rays $(\mathrm{C})$, scales in lateral line (Li), scales above lateral line (aLi), and 
scales below lateral line (bLi), gill raker on upper series (uGr), gill raker on lower series (lGr). Measurements included: standard length (SL), head length (HL), body width (BW), body depth (BD), caudal peduncle depth (CPD), caudal peduncle length (CPL), caudal concavity (CC), caudal fin base length (CBL), pre dorsal length (PDL), pre anal length (PAL), pre pectoral length (PPL), pre pelvic length (PVL), dorsal fin base length (DBL), longest dorsal spine (LDS), longest dorsal ray length (LDR), anal fin base length (ABL), longest anal spine (LAS), longest anal fin ray length (LArL), pectoral fin base length (PBL), longest pectoral fin ray length (LPrL), pelvic fin base length (VBL), longest pelvic fin ray length (LVrL), inter orbital length (IOL), pre orbital length (PrOL), post orbital length (PoOL), eye diameter (ED), snout length (SnL), upper jaw length (UJL), lower jaw length (LJL), jaw gape (JG).

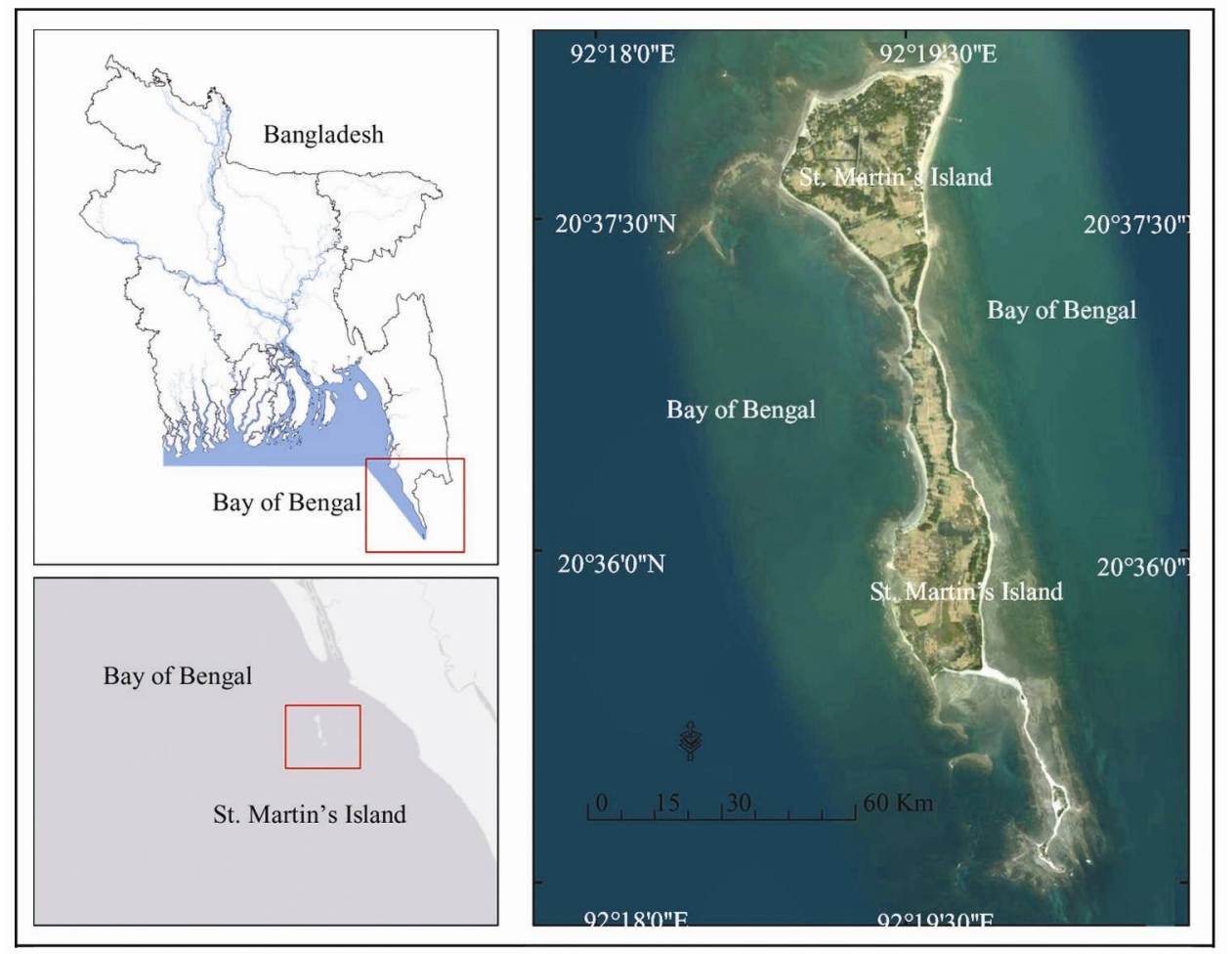

Fig. 1. The map of St. Martin's Island, Bay of Bengal, Bangladesh showing the location of sample sites of Lutjanus species.

Genomic DNA from 13 specimens representing 8 species was extracted by TIANamp Marine Animal DNA Kit. An $~ 655 \mathrm{bp}$ fragment was amplified from the 5 ' region of the cytochrome oxidase subunit I (COI) gene of mitochondrial DNA using the C FishF1t1/ C FishR1t1 primer cocktails (Ivanova et al. 2007). The 
PCR reactions were carried out in $20 \mu \mathrm{l}$ reaction mixture containing $6.0 \mu \mathrm{l}$ of distilled water, $10 \mu \mathrm{l}$ of master mix, $1 \mu \mathrm{l}$ of each primer $(5 \mu \mathrm{mol} / \mathrm{l})$ and $2 \mu \mathrm{l}$ of DNA template. The thermal regime consisted of an initial step of $2 \mathrm{~min}$ at $94^{\circ} \mathrm{C}$ followed by 35 cycles of $30 \mathrm{sec}$ at $94^{\circ} \mathrm{C}, 40 \mathrm{sec}$ at $52^{\circ} \mathrm{C}$, and $1 \mathrm{~min}$ at $72^{\circ} \mathrm{C}$, followed in turn by $10 \mathrm{~min}$ at $72^{\circ} \mathrm{C}$. Then soak at $4^{\circ} \mathrm{C}$. PCR products were purified by using QIA quick PCR purification kit. After purification, the products were sequenced in both directions by using commercial sequencer, Macrogen, Korea. Sequences were manually edited using the software Chromas Lite. Alignment and neighbor-joining tree (Saitou and Nei 1987) was constructed in MEGA 6 (Tamura et al. 2013) with 1000 bootstrapping replications based on evolutionary distances calculated using the Kimura two parameter (K2P) model (Kimura 1980).

\section{RESULTS AND DISCUSSION}

Details morphometric measurements of 8 Lutjanus spp showed in Table 1 and 6 Lutjanus species (L. vitta, L. rivulatus, L. johnii, L. fulviflamma, L. lutjanus and L. lemniscatus) identifying morphological characters comparison with other authors are summarized in Table 2. Details morphological description are provided for only the two new recorded species (L. xanthopinnis and $L$. indicus) individually. L. xanthopinnis ( 4 individuals), $L$. lutjanus ( 2 individuals) and $L$. vitta ( 1 individual) showed morphology are very similar (Fig. 2a,b,c and Table 5) but differentiated as 3 distinct species using both tools. Three (3) individuals of L. rivulatus (Fig. 2f,g) and seven (7) individuals of $L$. johnii (Fig. 2h, i, j) morphologically showed 2 and 3 types of marking patterns but confirmed as same species by both tools. Also marking variation confirmation in $L$. lemniscatus (SL, 21.2-26 cm) (Fig. 2k, 1).

Lutjanus xanthopinnis (Iwatsuki et al. 2015) represented by 4 individuals (7.5- $19.1 \mathrm{~cm} \mathrm{SL}$ ) were collected from fisherman at the fish landing zone of the study area. General body features are shown in Fig. 2a. Dorsal-fin with 10 spines and 13 rays, anal-fin with 3 spines and 8 rays, pectoral-fin with 16 rays, pelvic fin with 1 spine and 5 rays, caudal fin with 17 rays, lateral-line scales 50; scale rows transversely above lateral line 7 ; scale rows transversely below lateral line 14.

Description: Body elongated, laterally compressed. Dorsal profile convex, large in size. Head large and triangular, eye not at mid-level of head rather behind tip of snout. Posterior nostril is elliptical type (Fig. 3a). Small conical teeth on vomer, and both jaws have caniniform teeth with pair of dagger like canine in upper jaw anteriorly. Preopercle serrated. Large operculum with flap 


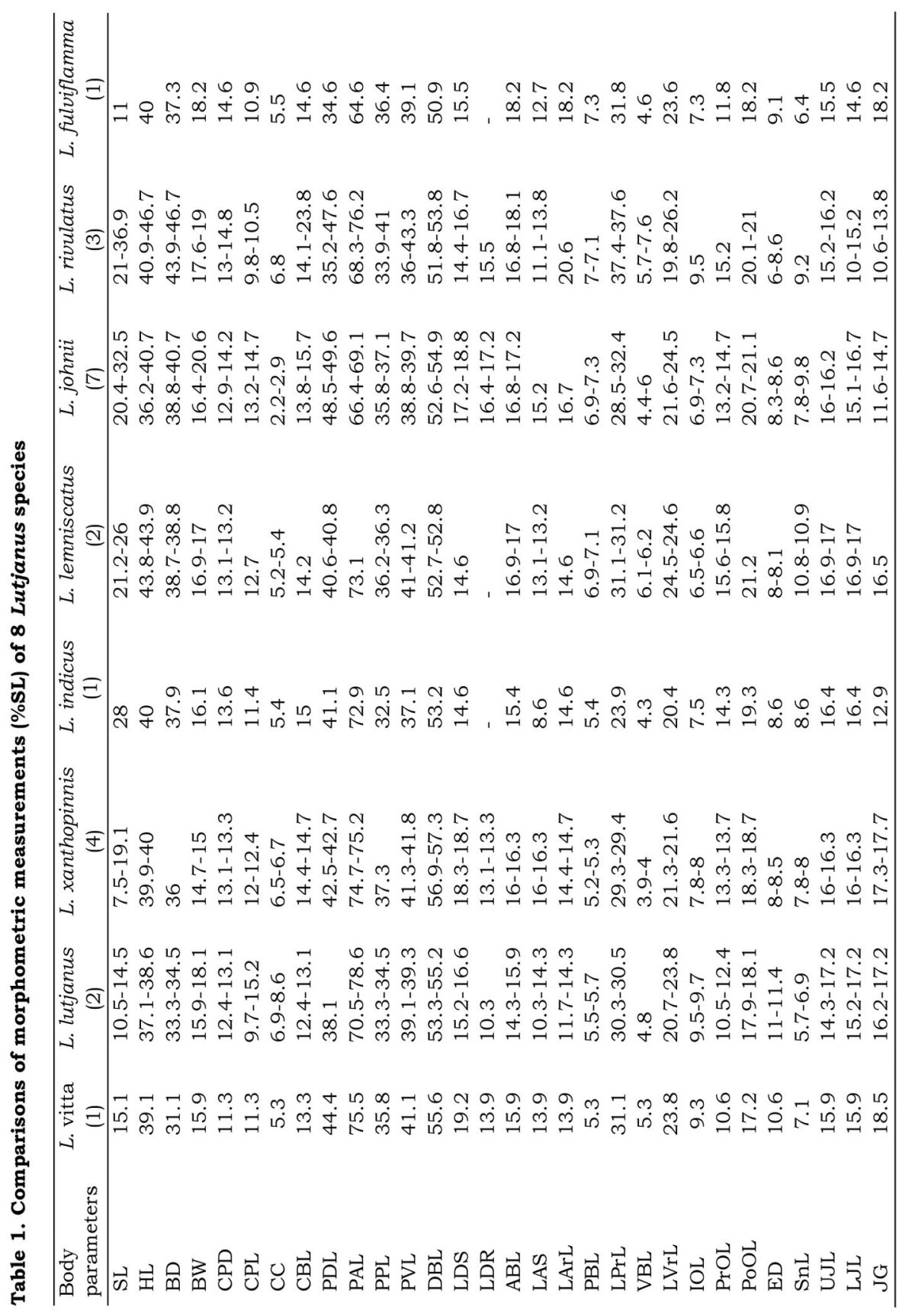




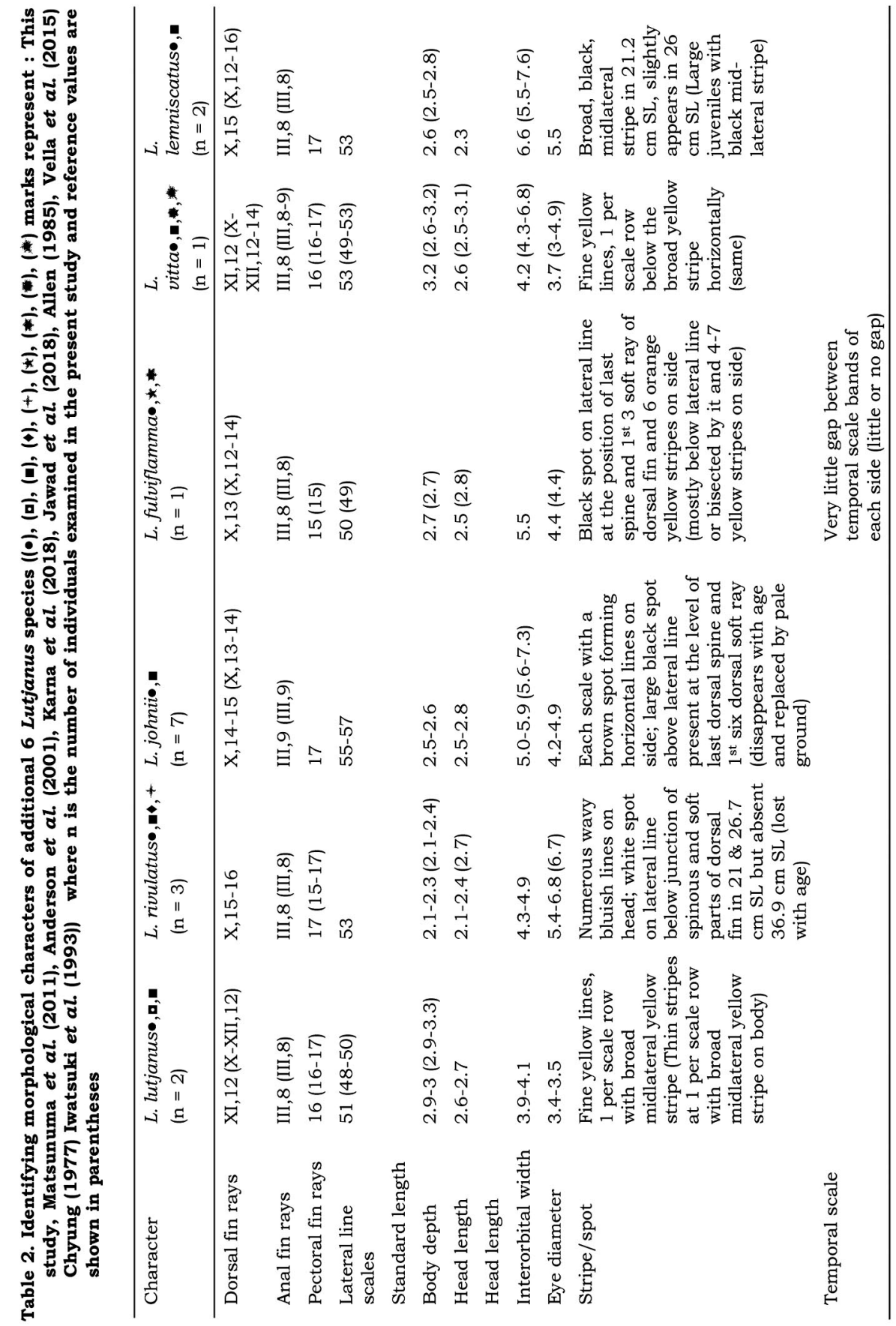


Number of individual are shown in parentheses
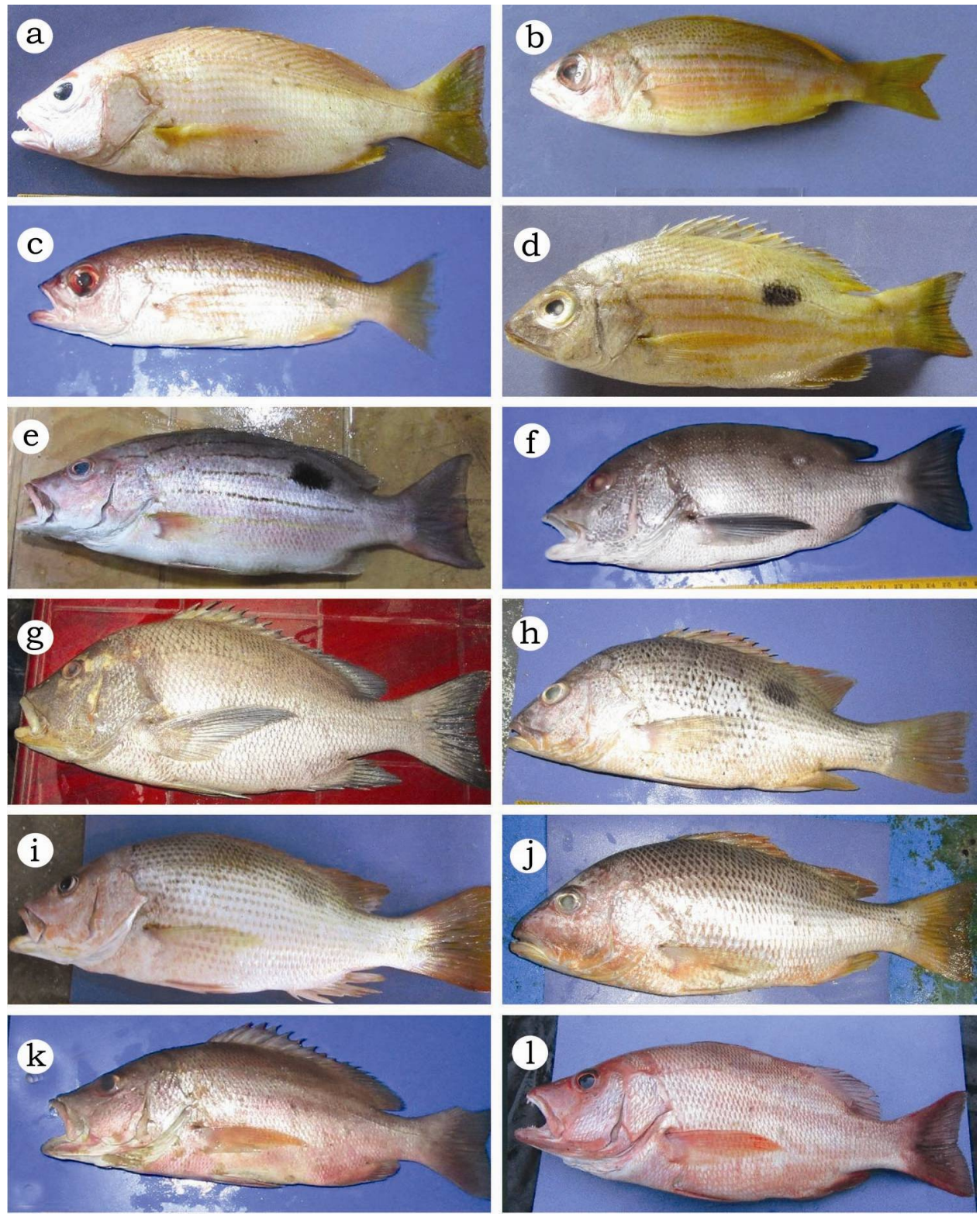

Fig. 2. Morphological representation of twelve species of Lutjanus used in the present study (a) Lutjanus xanthopinnis (15.3 cm SL); (b) L. lutjanus $(10.5 \mathrm{~cm} \mathrm{SL})$; (c) $L$. vitta $(15.1 \mathrm{~cm} \mathrm{SL);} \mathrm{(d)} L$. fulviflamma $(11 \mathrm{~cm} \mathrm{SL})$; (e) L. indicus $(28 \mathrm{~cm} \mathrm{SL})$; (f) L. rivulatus $(21 \mathrm{~cm} \mathrm{SL}$, white spot on lateral line); (g) L. rivulatus (36.9 cm SL, no spot on lateral line); (h) L. johnii (20.4 cm SL, black spot on lateral line distinctly appear); (i) $L$. johnii $(25.9 \mathrm{~cm}$ SL, black spot being disappear) and (j) $L$. johnii (32.5 cm SL, black spot completely disappear); (k) L. lemniscatus (21.2 cm SL) and (l) $L$. lemniscatus (26 cm SL). 
and large opening included 2 spines at the end of operculum. One rounded serrated bone above operculum. Scales are ctenoid type on body. Scale rows on back rising obliquely above lateral line. Five scale rows has on cheek (Fig. 3b). Pre-dorsal scales extending forward to about the middle of inter-orbital space (Fig. 3c). Moderately incised dorsal fin with $4^{\text {th }}$ spine longest $2.8 \mathrm{~cm}$ and longest dorsal ray length $2 \mathrm{~cm}$. Three rows of small scale on the soft dorsal fin base. Pectoral fin pointed. Caudal fin emarginated.

Color: Thin yellow stripes on the body. Body yellowish dorsally with 18 yellow oblique lines, light yellowish ventrally. Head light pinkish. Twelve fine yellow stripes horizontally, 1 per scale row below the lateral line. Dorsal, pectoral, pelvic, anal and caudal fin yellow.

Distribution: Indo-western Pacific: Japan, Taiwan, Indonesia and Sri Lanka. First described as a new species by Iwatsuki et al. (2015) from Indo-western Pacific region on the basis of the 11 specimen from Japan, Taiwan, Indonesia and Sri Lanka. All of the identifying characters in the present study show similarity with Iwatsuki et al. (2015) which is summarized in Table 3.
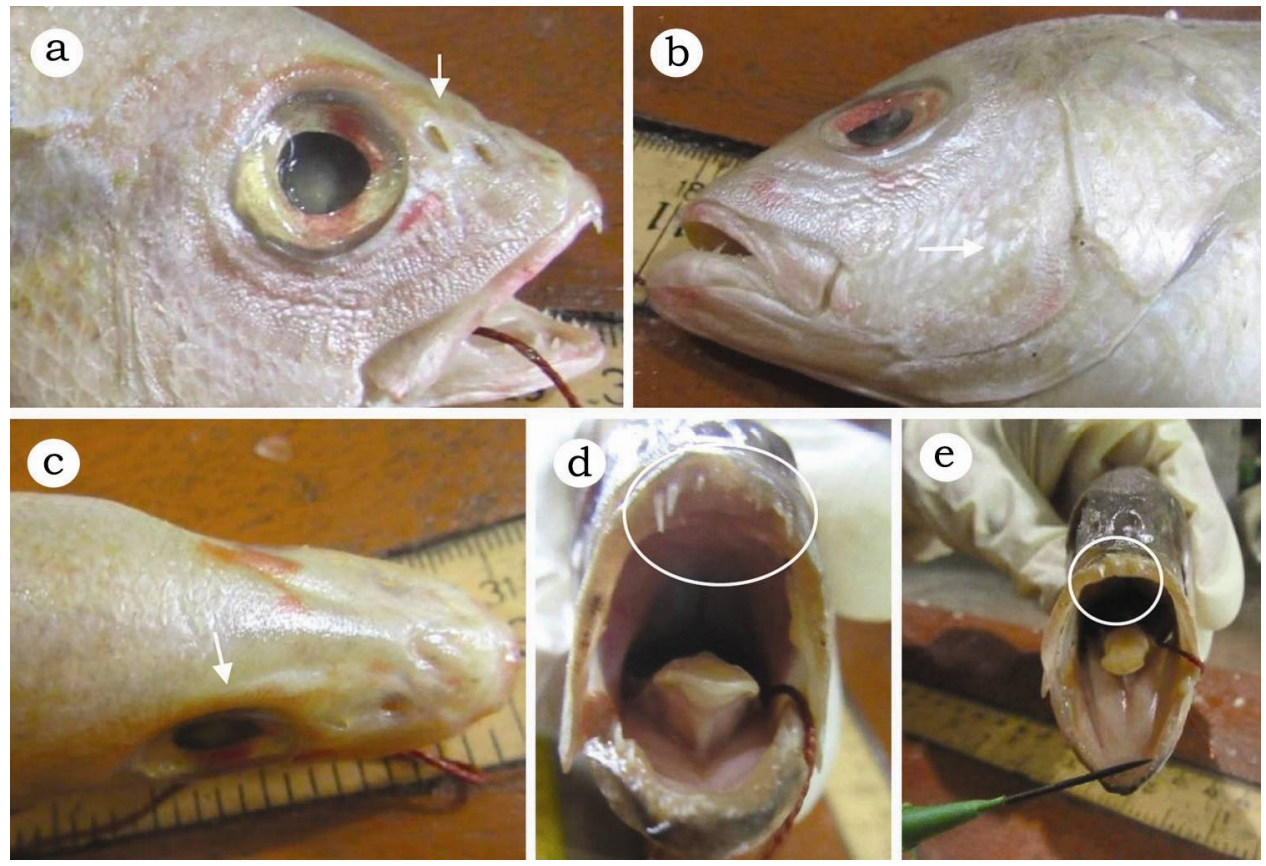

Fig. 3(a). Shape of posterior nostril, (b) scales on check and (c) extension of anterior predorsal scales in L. xanthopinnis; (d) 3 pairs of large canines in upper jaw of L. lutjanus; (e) pair of large canines in upper jaw of $L$. vitta. 
Table 3. Identifying morphological characters of four individuals of $L$. xanthopinnis

\begin{tabular}{|c|c|c|c|c|c|}
\hline Character & $\begin{array}{l}\text { L. xanthopinnis } \\
\text { (Present study) }\end{array}$ & $\begin{array}{l}\text { L. xanthopinnis } \\
\text { (Iwatsuki et al. } \\
\text { 2015) }\end{array}$ & Character & $\begin{array}{l}\text { L. xanthopinnis } \\
\text { (Present study) }\end{array}$ & $\begin{array}{l}\text { L. xanthopinnis } \\
\text { (Iwatsuki et al. } \\
\text { 2015) }\end{array}$ \\
\hline $\begin{array}{l}\text { Dorsal fin } \\
\text { rays }\end{array}$ & $\mathrm{X}, 13$ & $\mathrm{X}, 13$ & $\begin{array}{l}\text { Scale rows } \\
\text { above lateral } \\
\text { line }\end{array}$ & 7 & $6-7$ \\
\hline $\begin{array}{l}\text { Anal fin } \\
\text { rays }\end{array}$ & III, 8 & III, 8 & $\begin{array}{l}\text { Scale rows on } \\
\text { cheek }\end{array}$ & 5 & $4-5$ \\
\hline $\begin{array}{l}\text { Pectoral } \\
\text { fin rays }\end{array}$ & 16 & $16-17$ & $\begin{array}{l}\text { Size of } \\
\text { midlateral } \\
\text { yellow stripe }\end{array}$ & Very thin & Very thin \\
\hline $\begin{array}{l}\text { Body } \\
\text { depth }\end{array}$ & $2.7-2.8$ in $\mathrm{SL}$ & $2.7-2.9$ in SL & $\begin{array}{l}\text { Shape of } \\
\text { posterior } \\
\text { nostril }\end{array}$ & Elliptical & Elliptical \\
\hline $\begin{array}{l}\text { Lateral } \\
\text { line scales }\end{array}$ & 50 & $48-50$ & $\begin{array}{l}\text { Extension of } \\
\text { anterior } \\
\text { predorsal } \\
\text { scales }\end{array}$ & $\begin{array}{l}\text { middle of } \\
\text { interorbital } \\
\text { space }\end{array}$ & $\begin{array}{l}\text { middle of } \\
\text { interorbital } \\
\text { space }\end{array}$ \\
\hline
\end{tabular}

Lutjanus indicus (Allen et al. 2013) represented by single individual $(28.0 \mathrm{~cm}$ SL) and was collected from fish shop of the study area on 10 January 2016. General body features are shown in Fig. 2e.

Dorsal fin with 10 spines and 14 rays, anal fin with 3 spines and 8 rays, pectoral fin rays 15; pelvic fin with 1 spines and 5 rays, caudal fin rays 17 , lateral-line scales 49; scale rows transversely above lateral line 8; scale rows transversely below lateral line 17 .

Description: Body elongated, laterally compressed. Dorsal profile convex, large in size. Head large and triangular. Anterior and posterior nostrils elliptical shaped. Five scale rows on cheek. Small conical teeth on vomer, tongue and palatine. Upper jaw with pair of large dagger like canines anteriorly with smaller one middle of it and 12 relatively smaller canines on remaining lateral portion; lower jaw with 12 small canines on each side which become largest posteriorly and at back of jaw single row of 8 minute conical teeth. Preopercle posteriorly serrated. Large operculum with flap and large opercular opening. One rounded serrated bone just above the opercular opening. Dorsal fin incised, fifth spines longest $4.1 \mathrm{~cm}$. Pectoral fin elongated, 1.7 in HL. Pelvic fin relatively short, 2.0 in HL. Caudal fin double emarginated.

Color, stripe and spot: Blackish dorsally, side of the body light reddish and whitish ventrally. Head gray with preopercle and lip reddish. Lower side of body with series of 6 dark brown and 2 yellow (total 8) stripes on posterior head and side, first dark brown stripe starts from nape and reaches up to the fourth dorsal fin spine base; second dark brown stripe starts from just above the eye 
reaches up to the eighth dorsal fin spine base; third dark brown stripe starts from eye and reaches up to the fourth soft dorsal fin base; fourth dark brown stripe starts from lower margin of eye and reaches upto just above of broad black spot; fifth dark brown stripe starts from eye and reaches up to the lowermost part of broad black spot; sixth dark brown stripe starts from below eye, run along middle of opercle and reaches upto the caudal peduncle; seventh yellow stripe starts from the in front of preopercle, run along the above of pectoral fin and reaches up to the caudal peduncle; eighth yellow stripe starts from opercular opening and reaches up to the end of anal fin base. Prominent black spot, about 1.3 size of eye, on posterior back below base of first 8 soft dorsal rays, its lowermost part occupying about one scale row below lateral line.

Distribution: Distributed in northern continental margin of the Indian Ocean including western Thailand, Myanmar, Andaman Islands, Sri Lanka, India, Gulf of Oman and Arabian Gulf (FAO, 1985). Most of the identifying characters in the present study show similarity with Allen et al. (2013) and are shown in Table 4 except interorbital width in head length which is 5.3 in the present study and 5.9-7.0 as described in Allen et al. (2013); number of stripes on posterior head and side that are six dark brown and two yellow in the present study, where five dark brown and two yellow as described in Allen et al. (2013) and position of prominent black spot below base of first 8 soft dorsal rays (first 6-7 soft dorsal rays, Allen et al. 2013). Minor differences in above mentioned characters may be due to sampling from different geographical area.

Table 4. Identifying morphological characters of $L$. indicus of the present study with that of reported data

\begin{tabular}{|c|c|c|c|c|c|}
\hline Character & $\begin{array}{l}\text { L. indicus } \\
\text { (Present } \\
\text { study) }\end{array}$ & $\begin{array}{l}\text { L. indicus } \\
\text { (Allen et al. } \\
2013 \text { ) }\end{array}$ & Character & $\begin{array}{l}\text { L. indicus } \\
\text { (Present study) }\end{array}$ & $\begin{array}{l}\text { L. indicus } \\
\text { (Allen et al. 2013) }\end{array}$ \\
\hline Dorsal fin rays & $\mathrm{X}, 14$ & $X, 13-14$ & Head length & & \\
\hline Anal fin rays & III, 8 & III, 8 & Interorbital width & 5.3 & $5.9-7.0$ \\
\hline $\begin{array}{l}\text { Lateral line } \\
\text { scales }\end{array}$ & 49 & $47-49$ & Eye diameter & 4.6 & $4.2-4.6$ \\
\hline $\begin{array}{l}\text { Standard } \\
\text { length }\end{array}$ & & & $\begin{array}{l}\text { Stripes on posterior } \\
\text { head and side }\end{array}$ & $\begin{array}{l}6 \text { dark brown } \\
\text { and } 2 \text { yellow }\end{array}$ & $\begin{array}{l}7 \text { dark brown to } \\
\text { yellow stripes }\end{array}$ \\
\hline Body depth & 2.6 & $2.5-2.9$ & $\begin{array}{l}\text { Size of prominent } \\
\text { black spot }\end{array}$ & 1.3 size of eye & $\begin{array}{l}\text { about } 1.2-1.5 \mathrm{size} \\
\text { of eye }\end{array}$ \\
\hline Head length & 2.5 & $2.5-2.7$ & $\begin{array}{l}\text { Position of } \\
\text { prominent black } \\
\text { spot }\end{array}$ & $\begin{array}{l}\text { below base of } \\
\text { first } 8 \text { soft } \\
\text { dorsal rays }\end{array}$ & $\begin{array}{l}\text { below base of first } \\
6-7 \text { soft dorsal rays }\end{array}$ \\
\hline
\end{tabular}


According to the yellow lined snapper complex of Allen and Talbot (1985) and Iwatsuki et al. (2015) four more confusing Lutjanus species are $L$. lutjanus, $L$. vitta, L. xanthopinnis and L. madras. As present study described L. lutjanus, $L$. vitta and L. xanthopinnis, and L. madras (Iwatsuki et al. 2015) so, identifying meristic and morphological characters between them are summarized in Table 5.

Table 5. Comparision between 4 more closely related Lutjanus species

\begin{tabular}{|c|c|c|c|c|}
\hline Character & L. lutjanus & L. vitta & L. xanthopinnis & L. madras \\
\hline Dorsal fin rays & $\mathrm{XI}, 12-13$ & $\mathrm{XI}, 12$ & $\mathrm{X}, 13$ & $\mathrm{X}, 13$ \\
\hline Anal fin rays & III, 8-9 & III, 8 & III,8 & III,9 \\
\hline Lateral line scales & 51 & 53 & 50 & $49-51$ \\
\hline $\begin{array}{l}\text { Horizontal scale rows } \\
\text { above lateral line }\end{array}$ & $5-6$ & 8 & 7 & $7-8$ \\
\hline Scale rows on cheek & 5 & 6 & 5 & $7-8$ \\
\hline $\begin{array}{l}\text { Number of dagger-like } \\
\text { canines in upper jaw }\end{array}$ & 3 pair* & 1 pair" & 1 pair & 1 pair \\
\hline $\begin{array}{l}\text { Size of midlateral yellow } \\
\text { stripe }\end{array}$ & Broad & Broad & Very thin & Broad \\
\hline Shape of posterior nostril & Rounded & Rounded & Elliptical & Rounded \\
\hline $\begin{array}{l}\text { Extension of anterior } \\
\text { predorsal scales }\end{array}$ & $\begin{array}{l}1 / 3 \text { anterior of } \\
\text { eye }\end{array}$ & $\begin{array}{l}1 / 3 \text { anterior of } \\
\text { eye }\end{array}$ & $\begin{array}{l}\text { middle of interorbital } \\
\text { space }\end{array}$ & $\begin{array}{l}\text { posterior edge of } \\
\text { the orbit }\end{array}$ \\
\hline
\end{tabular}

*Fig. 3d \& \#Fig. 3e.

Sequence analysis of the COI gene: We amplified the COI gene fragments of 12 individuals representing 8 species of Lutjanus. All the COI sequences were submitted to GenBank. Including the downloaded COI sequences of congeners and conspecies, totally 32 sequences were used in the analysis. GenBank accession numbers of all $\mathrm{CO} 1$ sequences are provided in the associated figure. The mean intraspecies evolutionary divergence (K2P distance) was $1.5 \%$. The minimum and maximum intraspecies evolutionary divergence were $0 \%(L$. lutjanus) and $3.5 \%$ (L. lemniscatus) respectively. The mean, minimum and maximum interspecies evolutionary divergence were $12.5 \%, 0.8 \%$ (between $L$. lutjanus and $L$. vitta) and $16.9 \%$ (between $L$. xanthopinnis and $L$. rivulatus) respectively far exceeding the threshold of species delimitation (3.5\%) which was proposed and applied by Ward et al. $(2005,2009)$ based on the metric of $10 \times$ the average intra-species genetic variation (Herbert et al. 2004) except the minimum divergence, $0.8 \%$ between $L$. lutjanus and $L$. vitta. But these two species were distinctly separated based on morphometric measurements and meristics (details in Tables 1,2,5).

Neighbor-joining tree was constructed based on K2P model with 1000 replications of bootstrapping test. While DNA barcoding provides taxonomic 
identification for a specimen, the accuracy of such an assignment depends on whether species are monophyletic with respect to sequence variations of the COI gene. That is, individuals of a given species are more closely related to all other conspecifics than to any member of other species (Junbin 2011). In the phylogenetic analysis 5 individuals of the $L$. johnii formed a group in a monophyletic clade. Similarly, all other individuals of a species (conspecific) are monophyletic and formed a single clade. Individuals of the different species of the genus Lutjanus (congeneric species) are paraphyletic. Totally 10 species formed a polyphyletic tree (Fig. 4).

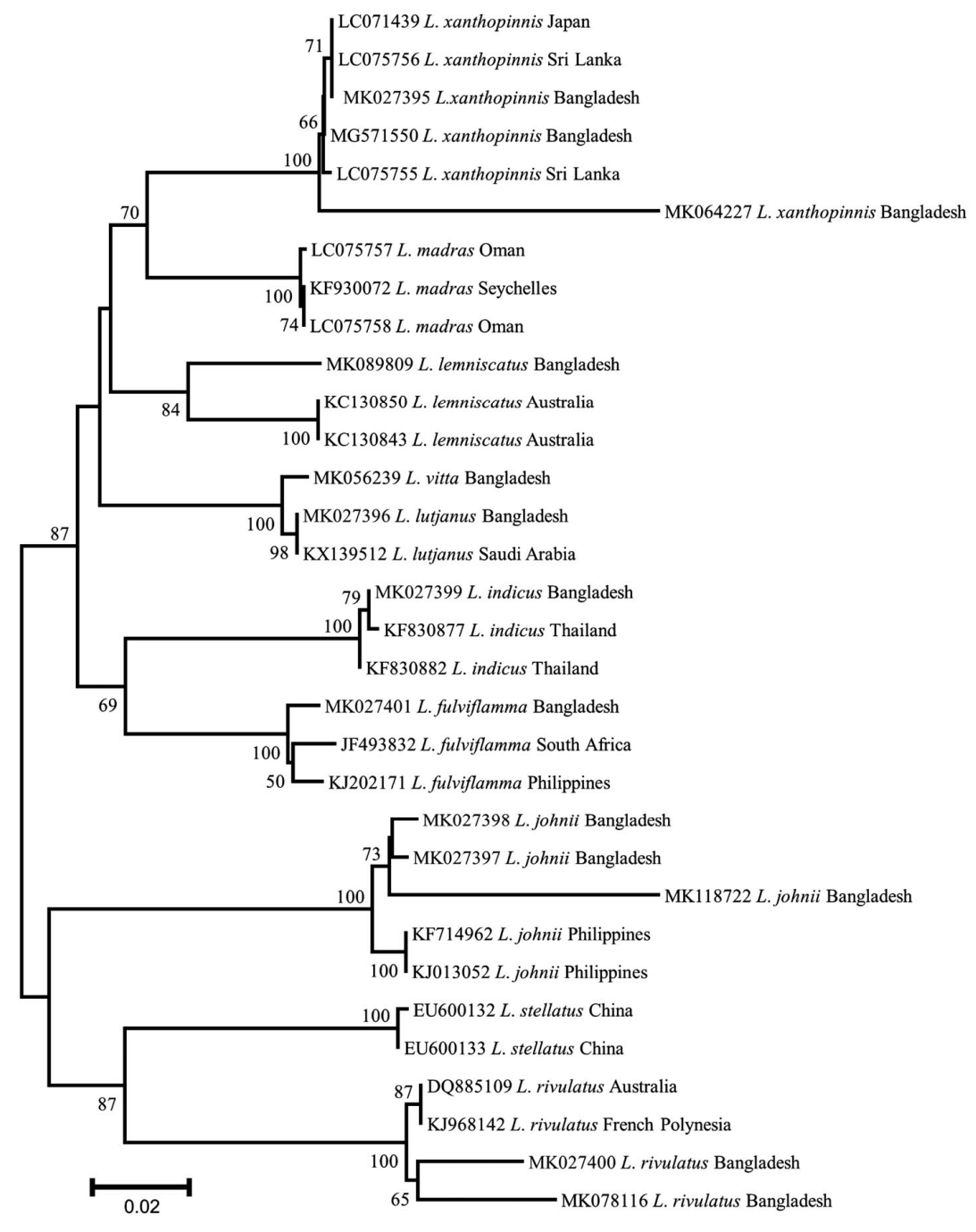

Fig. 4. Neighbor- joining tree constructed using the K2P model for COI gene sequences of ten species of Lutjanus. 
L. vitta has always been confused with its sibling species, L. lutjanus, $L$. xanthopinnis from Saint Martin's Island and L. madras from India. Genetic divergence of about $0.8,10.4$ and $7.7 \%$ was found between $L$. vitta and its closest congener, L. lutjanus, L. xanthopinnis and $L$. madras, respectively from comparison of the mitochondrial cytochrome c oxidase subunit 1 (CO1) genetic marker utilized in DNA barcoding. Also morphologically distinctly different from them. Close relation of $L$. xanthopinnis with $L$. madras from India, can be particularly differentiated by its elliptical posterior nostril. Genetic divergence of about $8.1 \%$ and $9.9 \%$ was found between $L$. xanthopinnis and its closest congeners, L. madras and L. lutjanus, respectively from comparison of the mitochondrial CO1 gene utilized in DNA barcoding.

\section{CONCLUSION}

The two newly recorded fish that are presented in this study provide new knowledge about their specific distributions and give an indication about their original distributions or possible range extensions. In either case, this information is important when it comes to conservation efforts for the species in question or, in a broader sense, for the entire Western Indo-Pacific or $\mathrm{N}$ ortheastern part of the Bay of Bengal biodiversity. With every new record, the marine biodiversity of the St. Martin's Island increases and may be much higher than previously assumed. This study also determines differentiation between cryptic L. lutjanus, $L$. xanthopinnis and $L$. vitta, and confirmation of standard length wise phenotypic variation in $L$. johnii and $L$. rivulatus.

Acknowledgments: We are thankful to SAU-KIOST collaborative project "Exploration of Coastal and Marine Biological Resources of Bangladesh" and Ministry of National Science and Technology for financial support in molecular part of this research work and local people of St. Martin's Island also for collection of fish.

\section{LITERATURE CITED}

ALLEN, G.R. 1985. FAO species catalogue. Snappers of the world. An annotated and illustrated catalogue of lutjanid species known to date. FAO Fish Synopsis FAO, Rome, No. 125, Vol. 6: 208 pp.

ALLEN, G.R. and TALBOT, J.H. 1985. Review of the snappers of the genus Lutjanus (Pisces: Lutjanidae) from the Indo-Pacific, with the description of a new species. Indo-Pacific Fish. 11: $1 \square 87$.

ALLEN, G.R., WHITE, W.T. and ERDMANN, M.V. 2013. Two new species of snappers (Pisces: Lutjanidae: Lutjanus) from the Indo-West Pacific. J ocea scifound. 6: 33-51.

ANDERSON, W.D., JR. and ALLEN, G.R. 2001. Family Lutjanidae. In: Carpenter, K.E. \& Niem, V.H. (Eds.) Species identification guide for fishery purposes. The living marine resources of the western central Pacific. Bony fishes part 3 (Menidae to Pomacentridae). FAO, Rome, pp. 2840-2918. 
BLOCH, M.E. 1790. Natural History of Foreign Fish. Berlin. Vol. 4.

CHYUNG, M. K. 1977. The fishes of Korea. Seoul:llchisa;

FAO. 1985. Species Catalogue: Snappers of the World: An Annotated and Illustrated Catalogue of Lutjaind Species Known to Date Fisheries Synopsis no: 125, Food and Agricultural Organization, Rome. Vol. 6

GAO, T.X., J.I, D.P., XIAO, Y.S., XUE, T.Q., YANAGIMOTO, T. and SETOGUMA, T. 2011. Description and DNA barcoding of a new Sillago species, Sillago sinica (Perciformes: Sillaginidae), from coastal waters of China. Zool. Stud. 50: 254-263.

GROSS, M. 2012. Barcoding biodiversity. Curr. Biol. 22: 73-76.

HERBERT P.D.N., STOECKLE M.Y., ZEMLAK T.S. and FRANCIS C.M. 2004. Identification of birds through DNA barcodes. P. Lib. of Sci. Biol. 2: 1657-1663.

IVANOVA, N.V., ZEMLAK, T.S. and HANNER, R.H. 2007. Universal primer cocktails for fish DNA barcoding. Mol Eco N. 4(7): 544-548.

IWATSUKI, Y., AKAZAKI, M. and YOSHINO, T. 1993. Validity of a lutjanid fish, Lutjanus ophuysenii (Bleeker) with a related species, L. vitta (Quoy et Gaimard). Jpn J Ichthyol. 40 (1): 47-59.

IWATSUKI, Y., TANAKA, F. and ALLEN, G.R. 2015. Lutjanus xanthopinnis, a new species of snapper (pisces: lutjanidae) from the indo-west pacific, with a redescription of lutjanus madras (valenciennes 1831). J ocea scifound. 17: 22-42.

JAWAD, L.A., AL-MARZOUQI, A.A., AL-ANBORY, I. and AL-SENAIDI, R. 2018. Range extension of Blubberlip Snapper Lutjanus rivulatus (Teleostei: Lutjanidae) to the Arabian Gulf. $J$ ocea sci found. 30: 78-81.

JUNBIN, Z. 2011. Species Identification of Marine Fishes in China with DNA Barcoding. EvidenceBased Comple. and Alter. Medi. Article $10 \mathrm{p}$.

KARNA, S.K., MANNA, R.K., PANDA, D., MANAS, H. M., MUKHERJEE, M. and SURES, V.R. 2018. Occurrence of Blubberlip snapper, Lutjanus rivulatus (Cuvier, 1828) from Chilika lagoon, India. Indian J Geo-Mar Sci. 47 (08): 1633-1635

KIMURA, M. 1980. A simple method for estimating evolutionary rates of base substitutions through comparative studies of nucleotide sequences. J Mol Evol. 16: 111-120.

MATSUnUmA, M., MOTOMURA, H., MATSUURA, K., SHAZILI, N. A. M. and AMBAK, M. A. 2011. Fishes of Terengganu - east coast of Malay Peninsula, Malaysia. National museum of nature and science, University Malaysia Terengganu and Kagoshima University Museum, ix+251 p.

QIN, Y., SONG, N., ZOU, J.W., ZHANG, Z. H., CHENG, G. P., GAO, T. X. and ZHANG, X.M. 2013. A new record of flathead fish (Teleostei: Platycephalidae) from China based on morphological characters and DNA barcoding. Chin. J. Oceanol. Limnol. 31: 617-624.

RAHMAN, A. K. A., KABIR, S. M. H., AHMED, M., AHMED, A. T. A., AHMED, Z. U., BEGUM, Z. N. T., HASAN, M. A. and KHONDKER, M. (eds.), 2009. Encyclopedia of Flora and Fauna of Bangladesh. Marine fishes. Asiatic Society of Bangladesh, Dhaka. 24: 485 p.

SAITOU, N. and NEI, M. 1987. The neighbor-joining method: A new method for reconstructing phylogenetic trees. Mol Biol Evol. 4: 406-425.

SARKER, M. M., BAKI, M. A. and SARKER, A. 2015. Taxonomic study of coral fish of Saint Martin's Island in the Bay of Bengal (Abstract). Marine conservation and blue economy symposium, 2015. Krishibid Institution of Bangladesh, Dhaka. http://www.saveoursea.social/

TAMURA, K., STECHER, G. and PETERSON D. 2013. MEGA6: Molecular Evolutionary Genetics Analysis Version 6.0. Mol Biol Evol. 30: 2725-2729.

TOMASCIK, T. 1997. Management plan for coral resources of Narikel jinjira (St. Martin's Island), national conservation strategy implementation project-1, Ministry of Environment and Forest, Government of Bangladesh. $126 \mathrm{p}$. 
VELLA, A., VELLA, N. and DARMANIN, S. A. 2015 First record of Lutjanus fulviflamma (Osteichthyes: Lutjanidae) in the Mediterranean Sea. J. Bla Sea/Mediter Env. 21(3): 307-315

WARD, R.D., HANNER, R. and HEBERT, P.D.N. 2009. The campaign to DNA barcode all fishes. $J$ Fish Biol. 74: 329-356.

WARD, R.D., ZEMLAK, T.S. and INNES, B.H. 2005. Barcoding Australia's fish species. Phil. Trans. R. Soc. London B 360: 1847-1857.

(Manuscript received on 19 November, 2018; 28 November, 2018) 